\title{
自由落下金属液滴の偏平・凝固に及ぼす基材温度の影響*
}

\author{
福本 昌宏**, 西岡 映二***, 松原 俊和****
}

\author{
Effect of substrate temperature on flattening and solidification of freely fallen metal droplet*
}

\author{
by Masahiro FUKUMOTO**, Eiji NISHIOKA*** and Toshikazu MATSUBARA****
}

\begin{abstract}
A freely falling experiment, in which a metal droplet fell freely and impinged on a flat substrate, was conducted as a simulation of the thermal spray process. The effect of substrate temperature on the flattening and solidification of the droplet was mainly investigated in this study.

The transition of the splat pattern was recognized in the experiment, that is, the splat morphology of $\mathrm{Ni}$ and $\mathrm{Cu}$ droplet on the room temperature substrate was splash-type, while that on the high temperature substrate was disk-type. The cross section microstructure of the splat on the room temperature substrate was composed of an isotropic coarse grain, while that on the high temperature substrate was quite fine columnar structure. As the mean interparticle spacing in the splat changed transitionally with the substrate temperature, the solidification rate in the splat on the high temperature substrate was higher than that on the room temperature substrate. The unique porous microstructure and flowing pattern were observed in the bottom surface of the splat on the room temperature substrate while the flat microstructure without pore was recognized in that on the high temperature substrate. The difference of the solidification rate between these two kinds of splats seems to be attributed to the interface microstructure between splat and substrate. From the results obtained in this study, it can be concluded that the quite rapid solidification occured at the interface between splat and substrate when the droplet impinged on the cold substrate surface.
\end{abstract}

Key Words : freely fallen droplet, splat, flattening, rapid solidification, substrate temperature, cooling rate

\section{1. 緒}

\section{言}

基材上における溶射粒子の偏平挙動について，理想的な 円盤状偏平としての偏平泍推定を試みる理論的1-5) あるい は数值解析的 ${ }^{6-9)}$ 取り組みが散見される。ただし現実の溶 射粒子偏平形態は必ずしも円盤状に限らず，溶射条件によ っては，むしろスプラッシュ状を呈する場合が少なくな (20).

著者らはこれまでの溶射粒子偏平に関する一連の研究に おいて，基材温度の上昇に伴い粒子偏平形態がスプラッシ

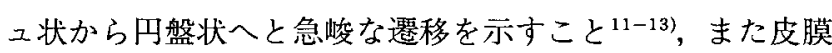
密着強度は円盤状偏平粒子の積層において優れること ${ }^{14,15)}$ などを明らかにした．特に，基材温度は溶射粒子の偏平形 態ならびに皮膜特性に対する主支配因子の一つであり，そ の管理が重要であること，また粒子偏平に対し基材温度の

*原稿受付 平成10年 7 月 14 日 平成 9 年度春季全国大会オ一ガ ナイズドセッションで発表

**正 員 豊橋技術科学大学 Member, Toyohashi Univ. of Technology

***学 生 員 豊橋技術科学大学（院） Student Member, Toyohashi Univ. of Tech., Graduate Student 豊橋技術科学大学 (院) Toyohashi Univ. of Tech., Graduate Student
変化は, 粒子内凝固挙動および粒子/基材界面奴挙動の変 化として関わっていることなどを指摘した，ただし，粒子 偏平に及ばす凝固およじぬれの両因子の影響の具体像は未 だ不明な点が多く，より詳細な観察を必要としている。

しかしながら実際の溶射粒子の基材上での偏平・凝固は 極めて短時間かつ微視的な現象であることから，現象のそ の場観察は現計測技術では困難と言わざるを得ない.この ため, 溶射現象の模擬として関与因子の設定が容易な液滴 の自由落下実験 ${ }^{16-18)}$ での取り組みが有効であり, 著者らも これまでに自由落下実験における円盤状スプラットの偏平 率等を種々調査し, 界面ぬれおよび凝固は液滴の偏平に対 し強く影響することなどを明らかにした ${ }^{199}$.

本研究では, 室温基材上においてスプラッシュ状偏平を 示す金属材料に着目し，基材温度変化に伴う液滴の偏平・ 凝固挙動変化を観察した。特に, 液滴の偏平における液滴 内凝固の影響について検討した。

\section{2. 供試材料および実験方法}

Fig. 1 に実験装置の概略を示す.液滴の形成は, 高周波誘 導加熱装置により原材料金属線を溶融・自然落下させるこ とによった，用いた金属線材料は，市販の純 $\mathrm{Cu}$ および純 $\mathrm{Ni}$ (ともに純度 $99.9 \%$ 以上， $\phi 2 \mathrm{~mm}$ ) である. Table 1 に

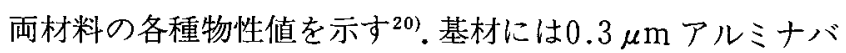


フ研磨による鏡面仕上げを施した $25 \mathrm{~mm} \times 25 \mathrm{~mm} \times$ 厚さ 5 $\mathrm{mm} の \mathrm{SUS} 304$ 鋼を用い, アセトンによる表面の洗浄・乾 燥を施した後に，K 型熱電対により温度を測定しながらホ ットプレートにより所定の温度に加熱保持した。

液滴の酸化を防止し，また種々の衝突速度を得るために， $0.15 \mathrm{~m}$ から0.9 m までの種々の長さのガラス管を準備し, ガラス管上部より窒素がスを充満させることにより不活性 雾囲気を形成した。本装置では, 形成される液滴直径の積 極的な制御は困難であるが，得られた液滴の平均直径を重 量計測により求めたところ, 約 $\phi 2 \pm 0.3 \mathrm{~mm}$ 程度であっ た。そこでこれを基に液滴の衝突速度を，代表的な溶射条 件と本模擬実験との間に流体的および熱的相似が成立する よう,すなわち両現象における Re 数および Pe 数が一致す

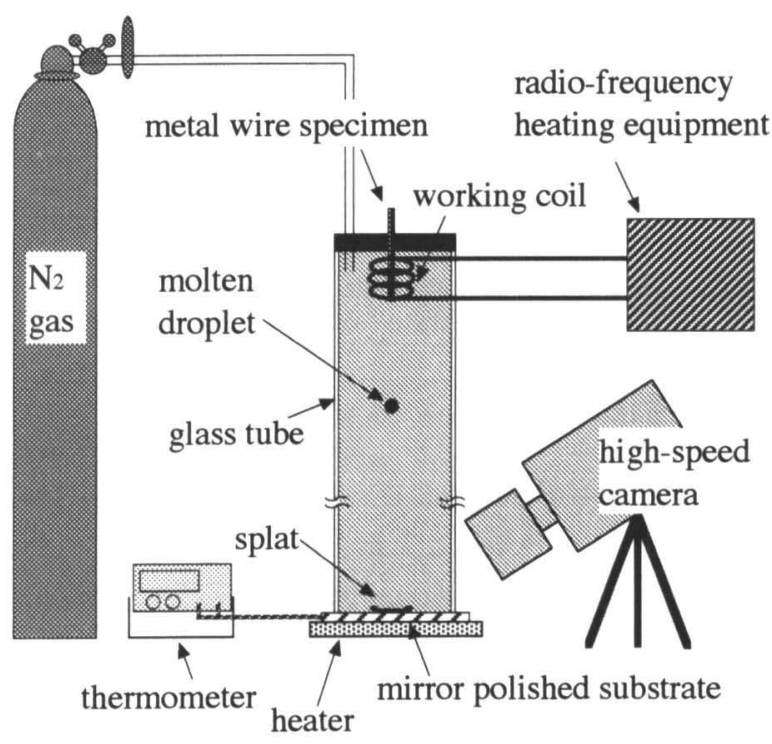

Fig. 1 Experimental apparatus.

Table 1 Physical properties of droplet materials used.

\begin{tabular}{|c|c|c|c|}
\hline \multicolumn{2}{|r|}{ Materials } & $\mathrm{Cu}$ & $\mathrm{Ni}$ \\
\hline \multirow{2}{*}{ 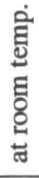 } & Specific heat $(\mathrm{J} / \mathrm{kg} / \mathrm{K})$ & 385 & 435 \\
\hline & Thermal conductivity $(\mathrm{W} / \mathrm{m} / \mathrm{K})$ & 394 & 88 \\
\hline \multirow{5}{*}{ 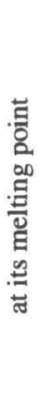 } & Melting point(K) & 1356 & 1727 \\
\hline & Latent heat $(\mathrm{J} / \mathrm{g})$ & 209.3 & 299.8 \\
\hline & Surface tension $(\mathrm{mN} / \mathrm{m})$ & 1285 & 1778 \\
\hline & $\operatorname{Viscosity}\left(\mathrm{mNs} / \mathrm{m}^{2}\right)$ & 4.0 & 4.9 \\
\hline & $\operatorname{Density}\left(\times 10^{3} \mathrm{~kg} / \mathrm{m}^{3}\right)$ & 8.0 & 7.9 \\
\hline
\end{tabular}

るように設定した．基材衝突直前の液滴速度は落下距離よ り算出した。なお本研究では液滴温度の測定は行わなかっ たが, 液滴の形成には金属線が溶融することが必要条件で あることから，液滴は両材料の融点以上の温度を有するも のとみなした.

また本実験では，基材衝突後の液滴の偏平過程を観察す るために，高速度ビデオカメラ (Photoron 社製 Fastcamultima）による撮影を行った．撮影コマ数は最適な撮影領

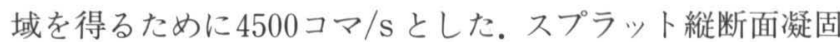
組織の観察には，硝酸 $(1.4 \mathrm{~N})$ とエチルアルコール $(96 \%)$ を 1：7の割合に混合した腐食液を使用し，腐食時間は腐 食進行程度に応じ $30 \mathrm{~s}$ から $180 \mathrm{~s}$ 程度とした。

\section{3． 実験結果および考察}

\section{1 液滴偏平形態の基材温度依存性}

初めに，溶射粒子で観察された基材温度の変化に伴う偏 平形態遷移現象の有無を, 本自由落下実験において調査し た. Fig. 2 に, 同一衝突速度条件の下に得た室温および加熱 保持した基材上での $\mathrm{Cu}$ および $\mathrm{Ni}$ のスプラット外観を示 す。室温基材上でのスプラットはスプラッシュ状であるの に対し，高温基材上では円盤状を呈した．著者らのこれま での研究において，両材料の溶射粒子にも基材温度変化に 伴う同様の粒子偏平形態遷移現象が認められたことから, 自由落下液滴と溶射粒子との間に偏平形態遷移現象の相似 性が確認された.

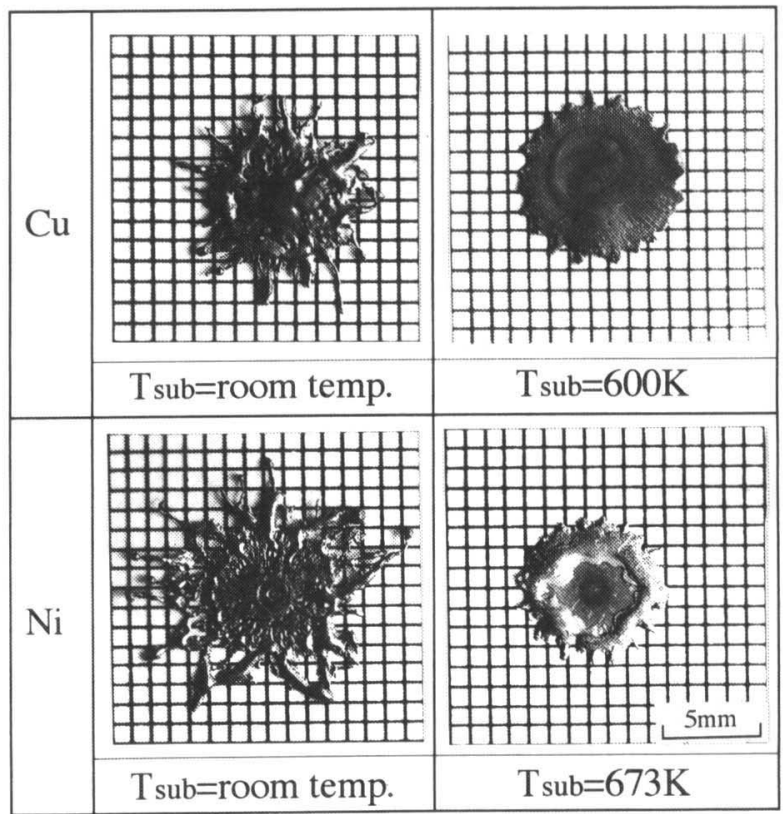

Tsub: Substrate temperature

Fig. 2 Observation results of splats morphologies. (impact velocity $4.0 \mathrm{~m} / \mathrm{s}$ ) 


\section{2 スプラット縦断面凝固組織}

このようなスプラット形態の遷移は，基材温度の上昇に 伴い発生することから, $\mathrm{Cu}$ スプラットの縦断面凝固組織を 観察した. Fig. 3 に室温および $600 \mathrm{~K}$ に加熱した基材上で 得たスプラット縦断面凝固組織観察例を示す。これより, いずれのスプラットにも外周付近を除きスプラット内は基 材面に直交する厚さ方向への一方向凝固組織が認められる こと, 凝固組織結晶粒の大きさには粒子内半径方向での顕 著な分布は認められず，ほぼ均一とみなされること，およ び結晶粒の大きさは室温基材上で得たスプラットでの方が 高温基材上でのそれよりも大きいことなどが分かった。こ のような一方向凝固組織からは，基材との界面近傍を除く スプラット内部の凝固は偏平のほぼ完了した後に起こり, 熱はスプラットの厚さ方向に移動したものと判断される.

得られた結果で特に興味深いのは, 凝固組織結晶粒サイ ズが予想に反し室温基材上での方が大きいことである. 室 温および高温基材上で得たスプラットの中心付近における 平均的な結晶粒組織の拡大図を Fig. 4 に示す。これより, 室温基材上での凝固組織は，厚さ方向に伸びる方向性を有 するものの, 徐冷却により形成されたと思われる等方的な 粗大結晶粒を呈するのに対し, 高温基材上での結晶粒組織 は, 厚さ方向に急速に凝固した微細な柱状晶組織を呈する. 一般に凝固組織の大きさは, 二ュートン冷却条件より, 液 滴/基材間の温度差が大きいほどスプラットが急速に冷 却・凝固され微細化すると考えられるが, 本実験結果はこ れとは逆の傾向を示した。

そこで基材保持温度変化に伴う凝固組織の大きさの変化 を系統的に調査した。このため, 液滴衝突速度ならびに基 材温度を種々変化させ， スプラット縦断面凝固組織におけ
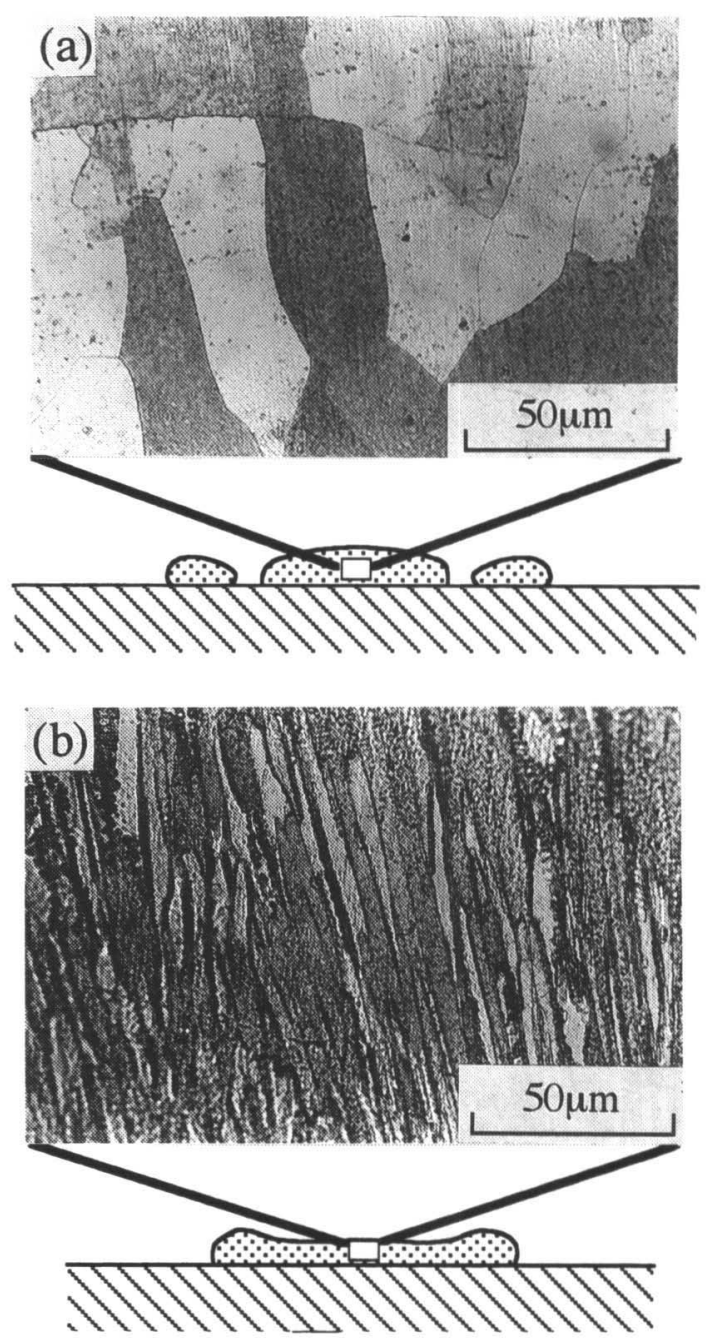

Fig. 4 Observation results of cross sections of $\mathrm{Cu}$-splats. (impact velocity $2.4 \mathrm{~m} / \mathrm{s}$ )

(a) $\mathrm{T}_{\text {sub }}=$ rom temp. (b) $\mathrm{T}_{\text {sub }}=600 \mathrm{~K}$

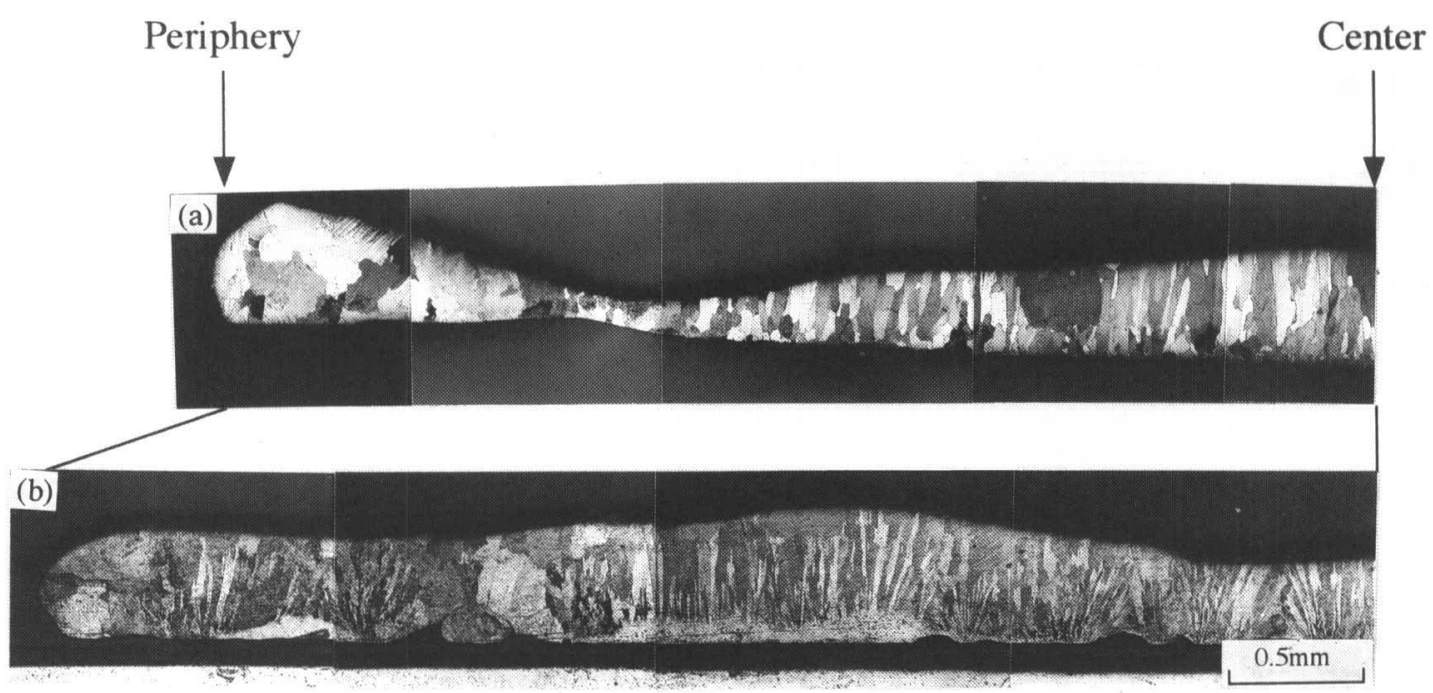

Fig. 3 Observation results of cross sections of $\mathrm{Cu}^{-}$-splats. (impact velocity $2.4 \mathrm{~m} / \mathrm{s}$ )

(a) $\mathrm{T}_{\text {sub }}=$ room temp. (b) $\mathrm{T}_{\text {sub }}=600 \mathrm{~K}$ 
る平均粒界距離との関係を整理した，得られた結果を Fig. 5 に示す.なお図中には, 観察されたスプラット形態も併示 した。これより，いずれの衝突速度の場合にも粒界距離は 基材温度の上昇に伴い遷移的に減少し，またこれに呼応し てスプラット形態も遷移することが分かった。

ここで，平均粒界距離 $\mathrm{L}$ と凝固速度 $\mathrm{S}$ との間には， $\mathrm{L}^{2} \times$ $\mathrm{S}=$ constant $^{21)}$ なる関係が存在することから，得られた結 果を基にスプラット内平均凝固速度を算出した. Fig. 6 に 基材温度と平均凝固速度との関係を示す。これより，室温 基材上でのスプラッシュ状スプラット内部での凝固速度

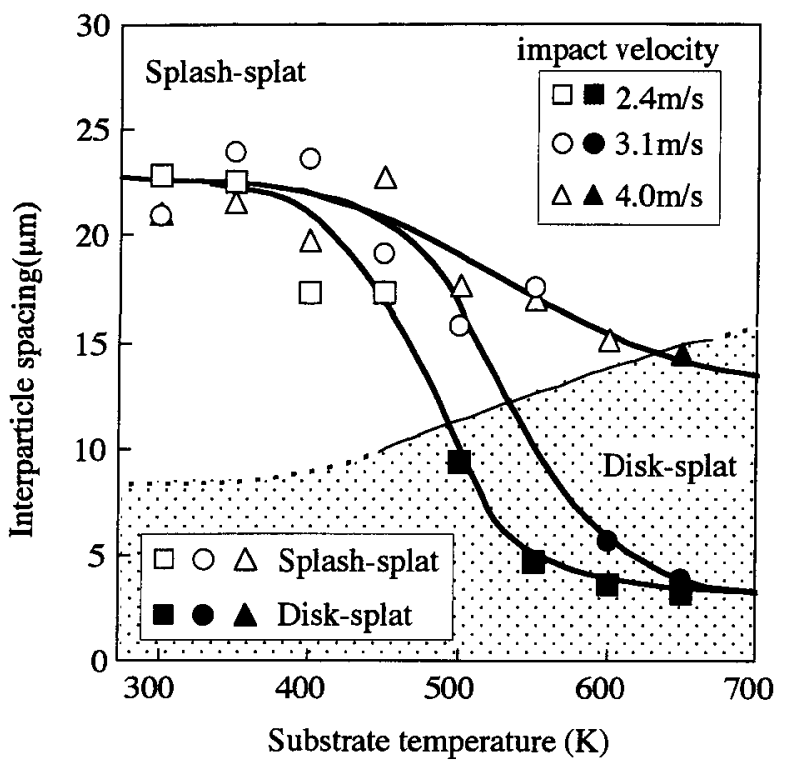

Fig. 5 Relation between substrate temperature and interparticle spacing.

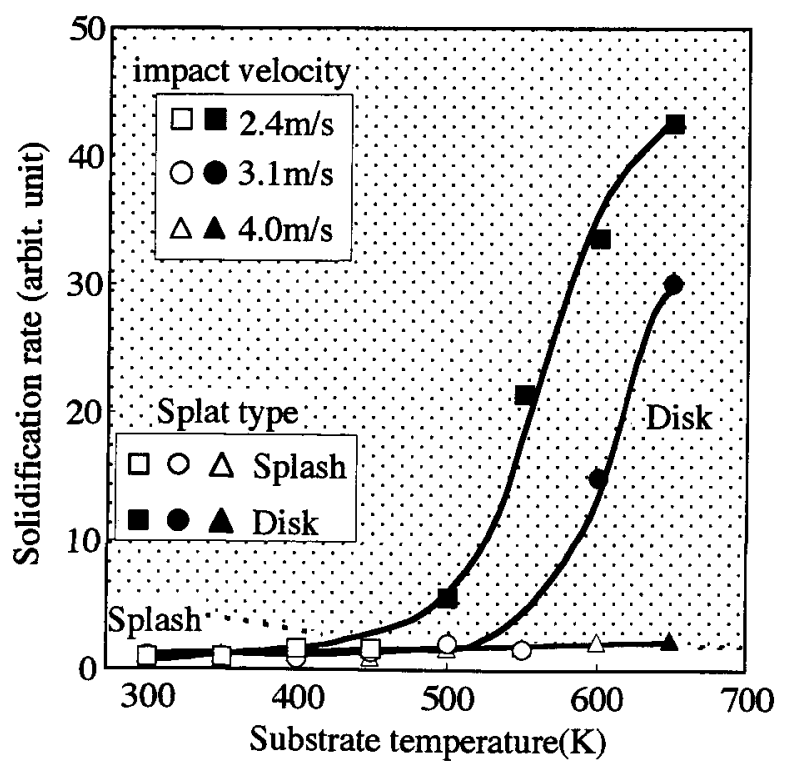

Fig. 6 Relation between substrate temperature and solidification rate.
は，高温基材上での円盤状スプラット内部でのそれよりも 格段に低いことが分かった。

\section{3 スプラット裏面組織観察結果}

Bianchi ら ${ }^{22)}$ は，異なる温度に保持した基材上における スプラットの平均冷却速度を実測した結果，室温基材上で のスプラット冷却速度は高温基材上のそれよりも低く，そ れはスプラット/基材界面接触抵抗の相違に起因すると推 察した。ただし同報告には，スプラット/基材界面組織等の 其体的な観察事実が示されておらず，界面接触抵抗の実像 は不明のままである。

本実験で得た基材温度の変化に伴うスプラット内凝固速 度の変化も同様に, スプラット/基材界面接触抵抗の変化に 起因すると予想されることから，得られたスプラットの裏 面組織を観察した。Fig. 7 に室温および高温基材上で得た $\mathrm{Cu}$ スプラットの裹面組織観察例を示す.これより，室温基 材上でのスプラット裹面には，中心部の極めて多孔質な組 織，および周辺に向けて放射状に伸びる気孔を有する特徵 的なフローパターンが認められる。このような裹面全面に わたる多孔質組織の形成原因については後に考察を加える が，観察された特有のフローパターン組織は，スプラット の流れがそのまま凝固凍結したことを意味しており，少な くとも液滴/基材界面部は, 接触した直後に急速に凝固した ものと考えられる。このような多孔質凝固組織は基材との 実質接触面積が小さいために熱伝達性が悪く，大きなスプ ラット/基材界面接触抵抗をもたらすものと思われる.

一方，高温基材上で得たスプラット䘚面中央部には，気 孔の少ない平滑な凝固組織が，また周囲部に向けては巨視 的な気孔を含まないストライエーション状模様を有する特 徵的な組織が認められる。このような裏面全体にわたる平 滑な凝固組織は, 室温基材上での多孔質な裹面組織に比べ, 基材との実質接触面積が大きいために熱伝達性が良く，す なわちスプラット/基材界面接触抵抗は小さいものと思わ れる。

\section{4 スプラット凝固冷却の基材温度依存性}

以上のスプラット縦断面凝固組織および裏面組織観察結 果より，スプラット凝固冷却挙動の基材温度（Ts）依存性 は Fig. 8 のように考えられる.すなわち，室温（Tr）に代 表される遷移温度 $(\mathrm{Tt})$ 以下の基材上でのスプラットにお いては，スプラット/基材間の温度差が大きい，すなわち凝 固のための駆動力が大きく，ニュートン冷却に従って，基 材に衝突・接触した部分が急速凝固する (図中 Sbに対応). ただしこの急速凝固層は多孔質であるために熱伝達性が極 めて悪く，一度形成されると，その後のスプラット/基材間 の熱流束を小さくし，結果としてスプラットの平均的な凝 固・冷却速度は低くなる (図中 $\mathrm{Si}$ )。一方，遷移温度以上の 高温 $(\mathrm{Th})$ に保持された基材上でのスプラットにおいては, 凝固のための駆動力は小さいもののスプラット/基材間の 


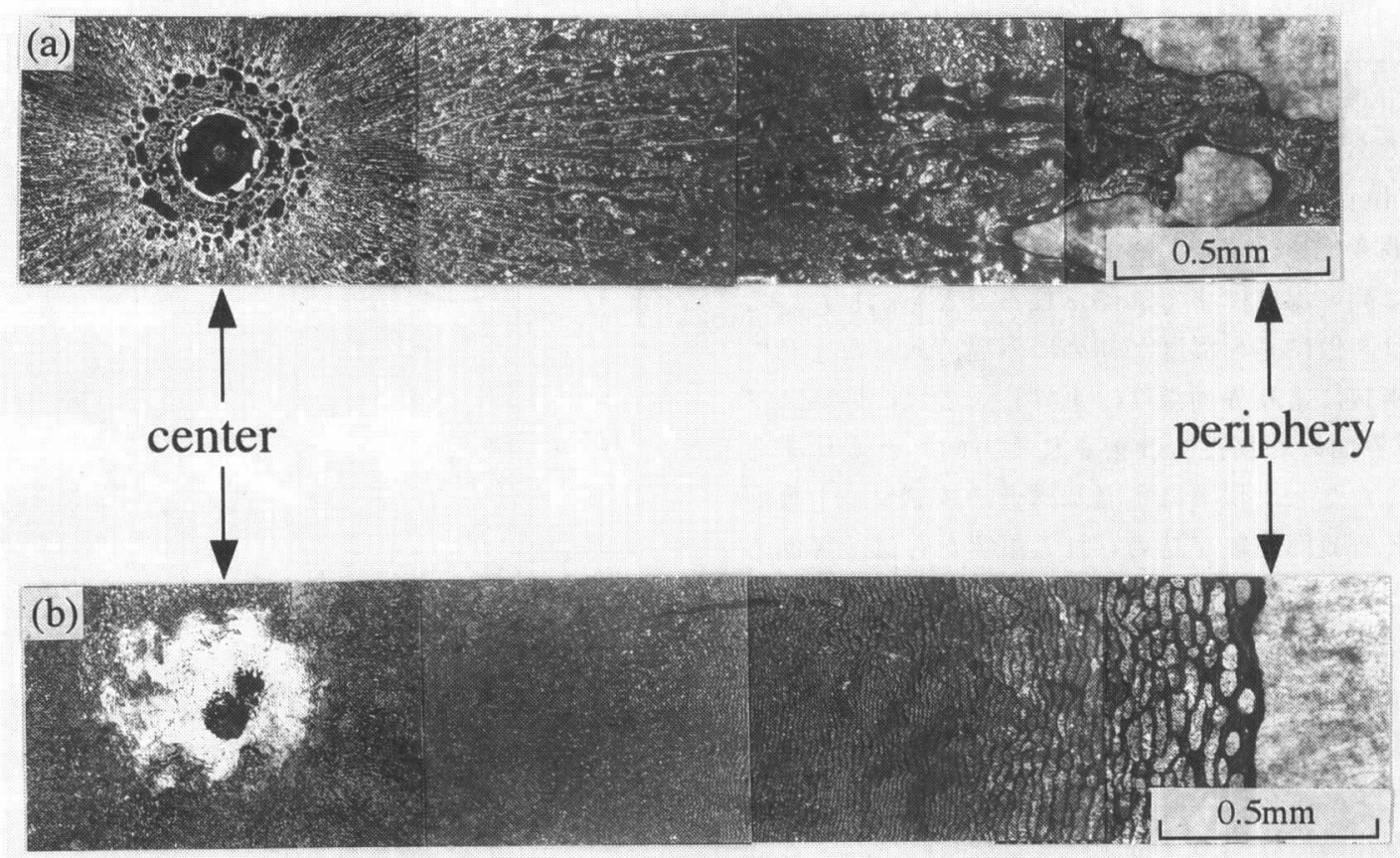

Fig. 7 Observation results of bottom surfaces of $\mathrm{Cu}^{-}$splats.

(impact velocity $2.3 \mathrm{~m} / \mathrm{s}$ )

(a) $\mathrm{T}_{\text {sub }}=$ room temp. (b) $\mathrm{T}_{\text {sub }}=600 \mathrm{~K}$

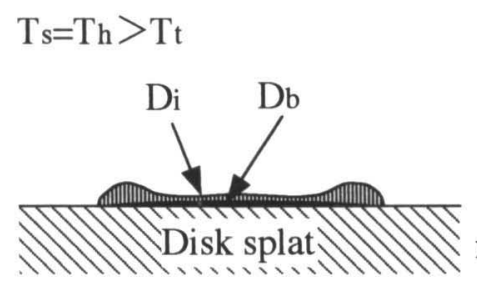

$\mathrm{T}_{\mathrm{s}}=\mathrm{Tr}<\mathrm{Tt}$

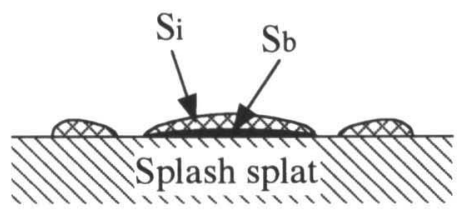

i:inside of splat

b:boundary layer in splat

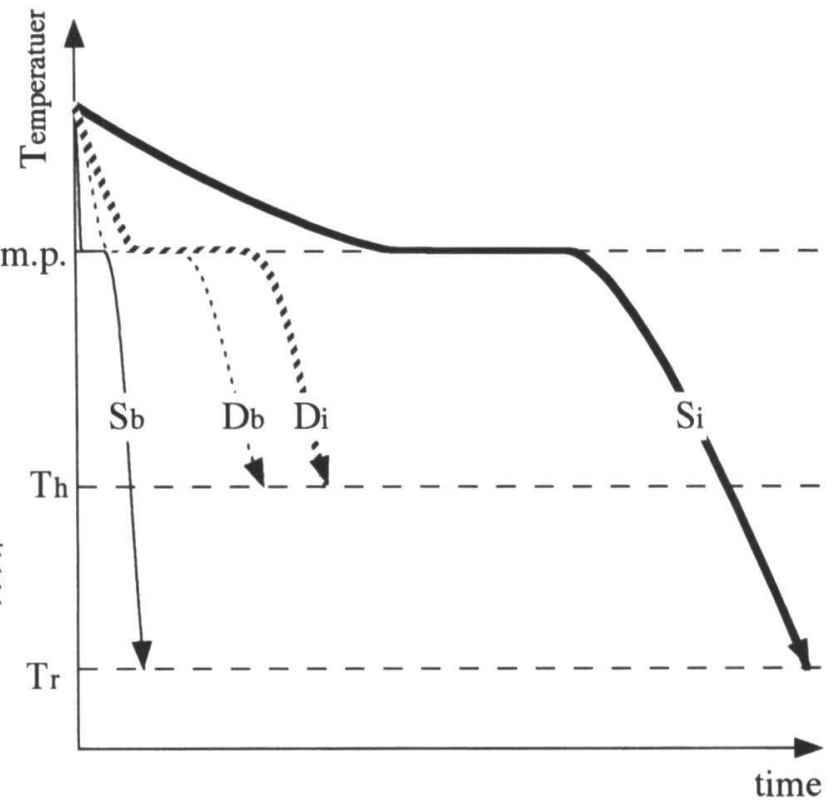

Fig. 8 Cooling and solidification process in splat.

接触状態がよく, 高い速度の下に凝固冷却が起こる（図中 Db, Di に対応).

以上の様に考えると, Bianchi ら ${ }^{22)}$ および Moreau ら ${ }^{23)}$ の室温基材上でのスプラット泠却速度が高温基材上でのそ れよりも低いとの実測結果は, 上述の粒子内平均冷却速度 の相違, すなわち四中の Di と Si との相違に対応するもの と理解される。
ここで，室温基材上でのスプラット亭面の多孔質凝固組 織の形成原因としては，1）液滴が偏平中にガスを物理的に 取り込んだ，2)液滴の溶融時に溶解したガスが凝固ととも に排出された，3）スプラット/基材間のぬれが悪かった，こ となどが考えられる，1）および2)は, 高温基材上でのスプ ラット偏平においても同様に作用寸ると考えられるが，高 温基材上では急速冷却が起こらず，仮に多孔質な組織が形 
成されても, 時間の経過とともにそれらは消失し, 密着性 のよい界面組織が形成されると考えられる。したがって, 多孔質凝固組織が残存するには, 衝突直後に起こる急速凝 固が不可欠である.

さらに Robert ら ${ }^{24)}$ は, 基材衝突後のスプラット/基材界 面温度の時間変化を推定し，界面は基材の融点に相当する 程度の十分に高い温度にまで加熱されることを示した。こ のことからは，仮に基材温度が初めに室温であったとして も, 液滴の衝突により界面温度は上昇し, これに伴いスプ ラット/基材界面のぬれ性も改善される方向へと変化する はずである、ただし，現実に室温基材上のスプラット裏面 において多孔質凝固組織が認められる事実からは，界面の ぬれが悪いということのみでは，かかる多孔質凝固組織の 形成原因にはなり得ない.

現時点では，いかなる原因によりこのような特徴的な多 孔質凝固組織が形成されたのかは依然不明であるが，いず れの原因にせよ，基材衝突直後に急速な凝固が起こらなけ れば，かかる組織形成はあり得ないことから，少なくとも 室温基材上では基材衝突直後において急速初期凝固層の形 成があり，この急速凝固層の存在が液滴の偏平凝固冷却に 対し影響を及ぼしていると考えられる。

\section{5 液滴偏平挙動の基材温度依存性}

基材温度変化に伴う液滴偏平挙動の変化を, 高速度ビデ オカメラによりその場観察した. 結果の一例として, Cu 液 滴よりも高融点で輝度の高い $\mathrm{Ni}$ 液滴について得た室温お よび高温保持基材上でのスプラットの高速ビデオ画像を Fig. 9 に示す.これより, 室温基材上でのスプラットは衝突 直後（n=2）に液膜先端部でのスプラッシュを形成しなが ら急速に偏平するのに対し, 高温基材上でのスプラットは, 衝突直後からほぼ円盤形状を保ちながら偏平する様子が突 之る.

このようにして得た高速度ビデオ画像より，時間経過に 伴うスプラット偏平率, 偏平速度および偏平加速度の変化 を整理した. Fig. 10 に，スプラッシュ状スプラットのスプ ラッシュ部外径および円盤状スプラットの外径の時間変化 を示す。ここで横軸には，個々の液滴の衝突速度および原 直径(d)の違いの影響を無くすために, 無次元時間 $\mathrm{t}^{*}=\mathrm{V}_{0} \mathrm{t} /$ $r_{0}$ をとっている.ここに, $V_{0}$ : 衝突速度, $t$ ：実時間, $r_{0}$ : 液滴半径である。これより，スプラッシュ状スプラットに おける最終偏平率，偏平速度および偏平加速度は，いずれ も円盤状スプラットのそれらを大きく上回ることが明らか である。すなわち，室温基材上でのスプラッシュ状スプラ

卜は，基材衝突直後に急速に偏平拡大寸ることが特徴で ある。

ここで，急速な偏平とスプラッシュ発生との関係につい て，液膜の不安定性の観点より考察した。一般に体積力場 における成層流の界面不安定を Rayleigh-Taylor 不安 定 ${ }^{25-27)}$ と呼び，密度の異なる2種の流体が境界線に垂直方

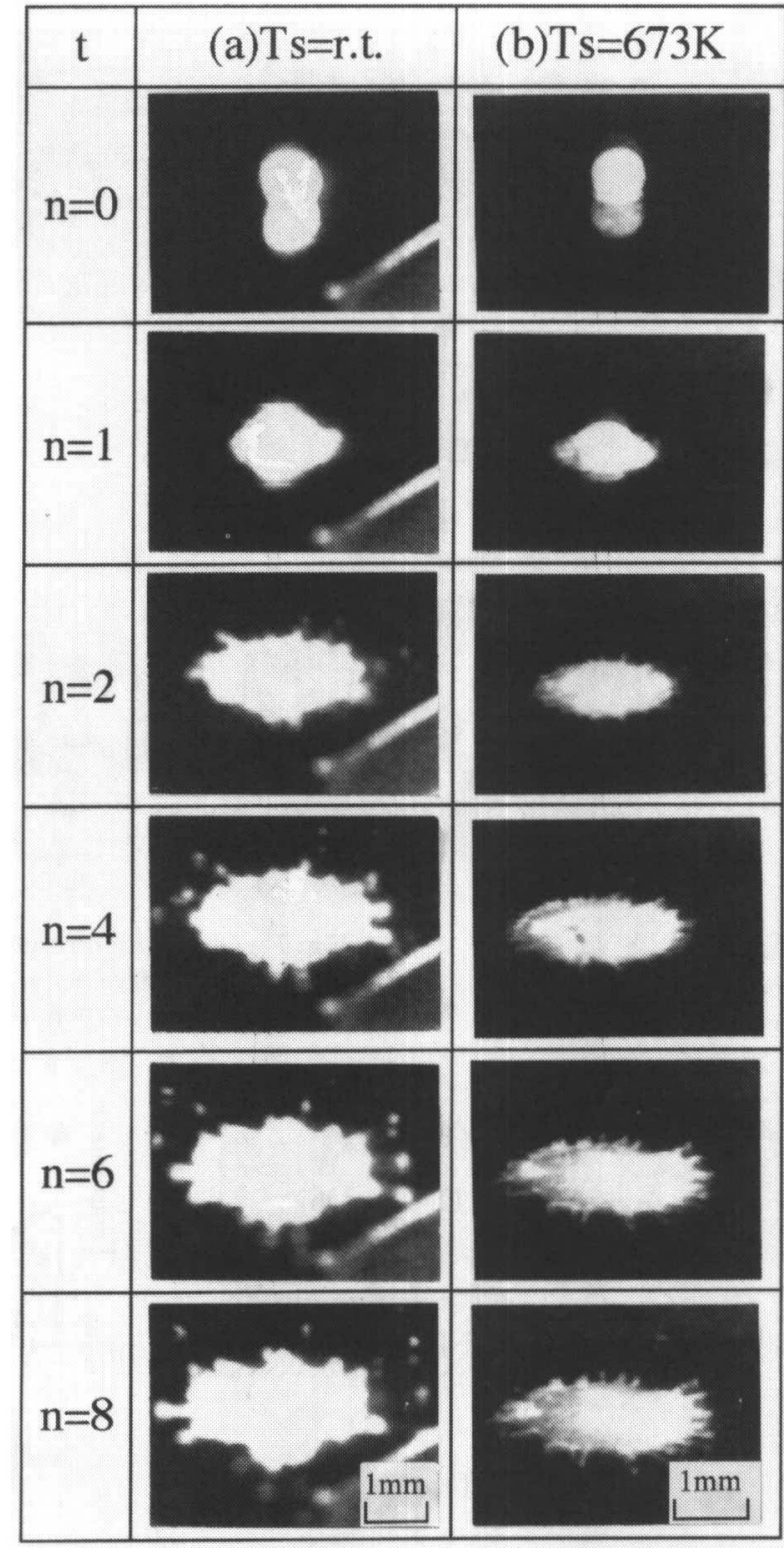

$\mathrm{t}=\mathrm{n} / 4500(\mathrm{~s})$

Fig. 9 Time-dependent flattening of Ni droplet by impact on SUS304 substrate.

向に加速度運動する際に，その境界線が不安定になる現象 を指す.この場合, 流体の境界線における波長は次式で与 えられる。

$$
\lambda=2 \pi\left(3 \gamma_{\mathrm{d}} / \mathrm{a} \cdot\left(\rho_{1}-\rho_{\mathrm{a} \text { ir }}\right)\right)^{0.5}
$$

ここに, $\lambda$ ：スプラット外周の波長， $\gamma_{\mathrm{d}}$ ：液滴の表面張 力, $\mathrm{a}$ ：液膜の偏平加速度, $\rho_{1}$ および $\rho_{\mathrm{a} i \mathrm{r}}$ : 液滴および空気 の密度である。上式において, 表面張力および密度は基材 温度に依存しないため, スプラット外周の波長は液膜の偏 平加速度のみに依存する。ここで，室温㧍よび高温基材上 でのスプラットの偏平加速度を比較すると, Fig. 10 (c)より 室温基材上でのスプラットの偏平加速度が格段に大きいこ 
とから,この過大な偏平加速度は液膜周囲の波長を短くし， この波長を保ちながら時間経過ととも振幅が増大すること
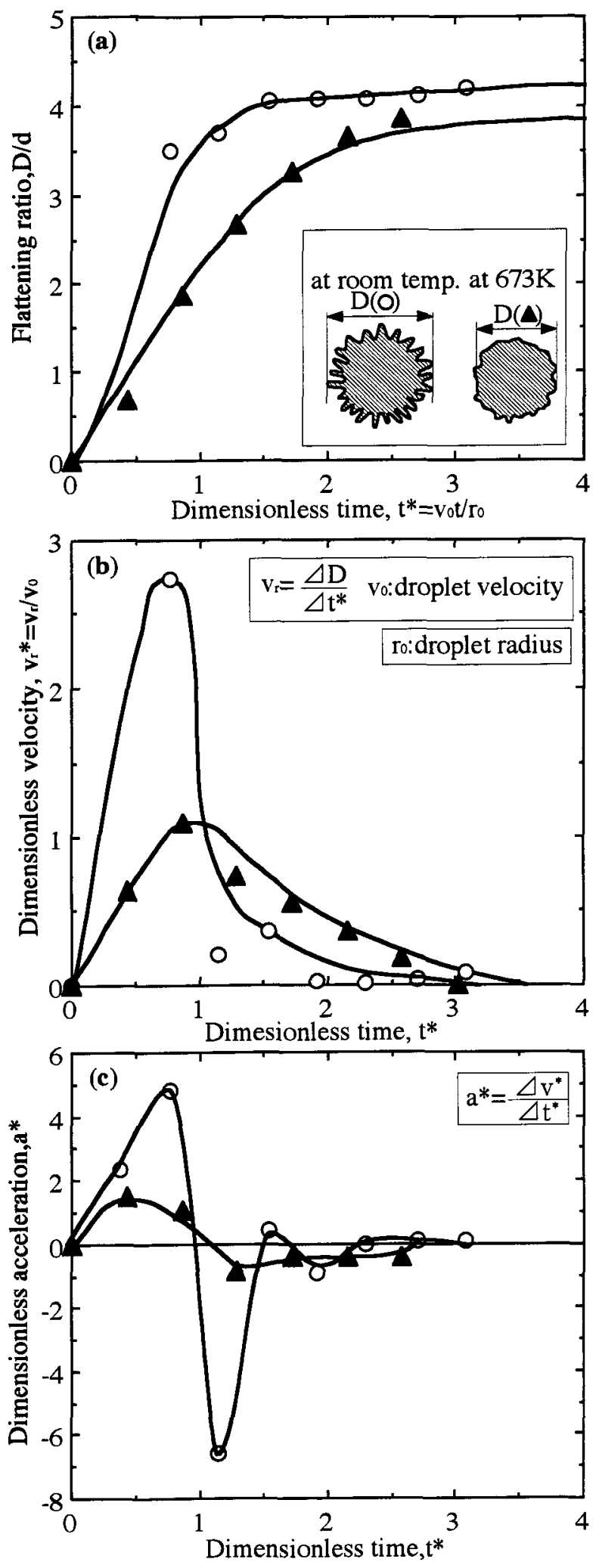

Fig. 10 Flattening behavior of $\mathrm{Ni}$ droplet. (a) flattening ratio (b) dimensionless velocity (c) dimensionless acceleration
により，室温基材上でのスプラットはスプラッシュを形成 するものと推察される。

\section{6 自由落下液滴のスプラット偏平・凝固機構}

以上の結果を総合し，自由落下金属液滴におけるスプラ ッシュ状および円盤状スプラットの偏平・凝固機構を以下 のように整理した。

初めに Fig. 11(a)に，室温基材上でのスプラッシュ状ス プラットの偏平・凝固モデルを示す。この場合, 液滴は基 材衝突直後に基材への接触部近傍が急速凝固し, 界面に極 めて多孔質な初期凝固層を形成する。この多孔質層は， ス プラット/基材間の熱伝達性を著しく低下させるためにス プラット内は断熱状態のままで偏平を続け，液滴内温度降 下の小さい分，粘性率はほとんど増大することなく，低粘 性の液滴が急速に周囲に向けて液膜として拡大偏平する. このような急速な拡大偏平が液膜先端部の不安定を引き起 こす結果，スプラッシュ状スプラットを形成する。

(a)

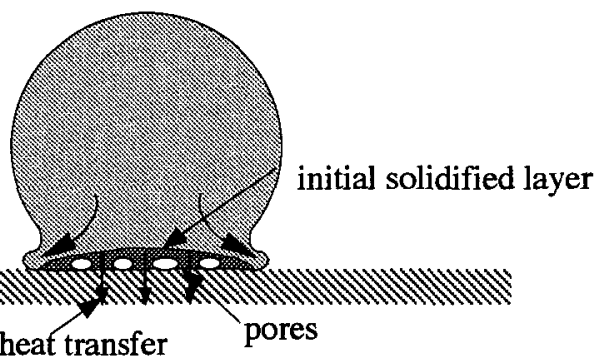

ultra rapid heat transfer

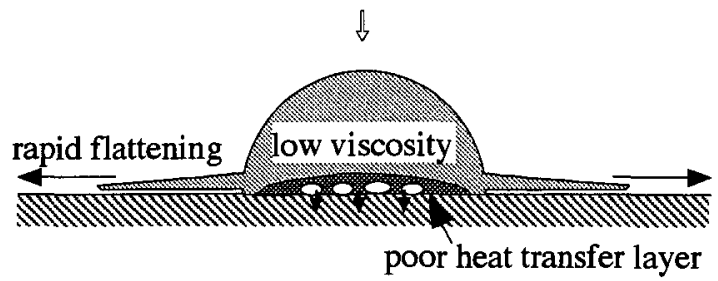

(b)

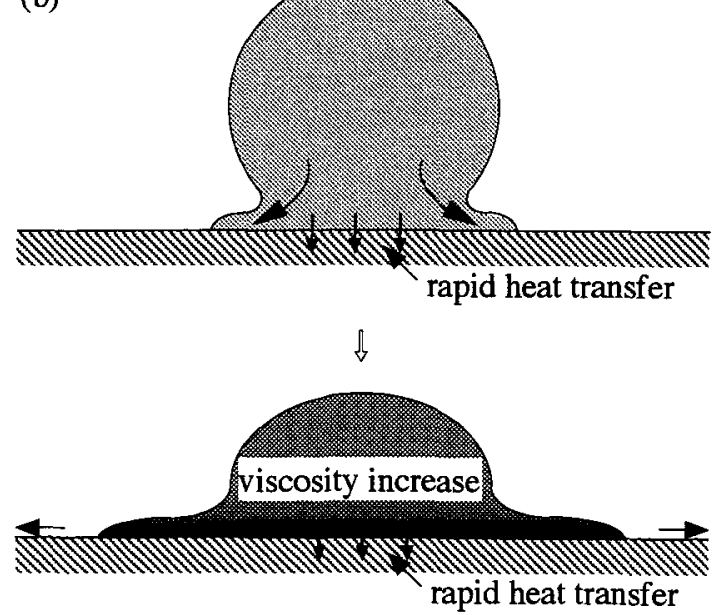

Fig. 11 Flattening and solidification process. (a) on room temp. substrate (b) on high temp. substrate 
一方，高温基材上での円盤状スプラット形成モデルを Fig. 11 (b)に示守。この場合は基材温度が高いために初期凝 固層の形成は抑制され，また界面でのぬれ性が良いことか らスプラット/基材間の接触状態は良く, スプラット内は急 冷却される。これに伴い液滴の粘性は急増し，高粘性状態 での偏平により，連動エネルギーの多くが効率的に粘性工 ネルギーにより消費されるために低速偏平し，結果的に円 盤状スプラットを形成する。

ただし本モデルは，室温および高温基材上での液滴の偏 平・凝固挙動を比較したに過ぎず，ぬれおよび凝固の影響 度合いは基材温度に対し徐々に変化し，遷移温度において 急変する性質のものではないと思われるため，遷移温度近 傍において偏平形態の急変する理由については依然不明で あり，今後の詳細な検討を要する。

\section{4. 結言}

基材温度変化に伴う自由落下金属液滴の偏平 ・凝固挙動 変化を観察し，特に液滴偏平に対する液滴内凝固の影響に ついて検討を試みた結果，以下の諸点を明らかにした。

1）自由落下液滴と溶射粒子との間に偏平形態遷移現象 の相似性が確認された。

2）室温基材上でのスプラット凝固組織は徐冷却により 形成されたと思われる等方的な粗大結晶粒を呈するのに対 し, 高温基材上での結晶粒組織は, 厚さ方向に急速に凝固 した微細な柱状晶組織を呈した。

3）結晶粒界距離は基材温度の上昇に伴い遷移的に減少 しまたこれに呼応してスプラット形態も遷移した。

4）室温基材上でのスプラット裹面は多孔質凝固組織を 呈した。このような多孔質凝固組織は基材との実質接触面 積が小さいため熱伝達性が悪く,大きなスプラット/基材界 面接触抵抗をもたらす。一方，高温基材上でのスプラット 稟面は気孔の少ない平滑な凝固組織を呈した，裏面全体に わたる平滑な凝固組織は基材との実質接触面積が大きいた めに熱伝達性が良く，界面接触抵抗は小さいものと思われ る.

5）スプラット/基材界面のぬれの悪さのみでは多孔質 凝固組織の形成原因にはなり得ず，これには基材衝突直後 に起こる初期急速凝固が不可久である.

6）室温基材上でのスプラッシュ状スプラットは，基材 衝突直後に液膜が急速に拡大偏平することにより形成さ れ，スプラッシュ形成は急速流れによる液膜先端部の不安 定に起因することが示唆された。

\section{参考文 献}

1) H. Jones, J. Phys. D : Appl. Phys., 4 (1971) 1657.

2) J. Madejski, Int. J. Heat Mass Transfer, 19 (1976) 1009.

3) G. Trapaga and J. Szekely, Met. trans., 22B (1991) 901.

4) G. Trapaga, E.F. Matthys, J.J. Valencis and J. Szekely, Met. trans., 22B (1992) 701.

5) J.P. Delplanque and R.H. Rangel, J. Mat. Sci., 32 (1997) 1519.

6) M. Bertagnolli, M. Marchese, G. Jacucci, I.S. Doltsinis and S. Noelting, Materials and design technology, PD-62 (1994) 199.

7) M. Bertagnolli, M. Marchese and G. Jacucci, J. Thermal Spray Technology, 4 (1995) 41.

8) M. Pasandideh-Fard and J. Mostaghimi, Plasma Chemistry and Plasma Processing, 16-1 (1996) 83.

9) M. Pasandideh-Fard, Y.M. Qiao, S. Chandra and J. Mostaghimi, Phys. Fluids, 8-3 (1996) 650.

10）丸尾 大，平田好則，紀之定邦夫，松本泰一，日本溶射協会第 55 回講演論文集 (1992) 76.

11）福本昌宏, 加藤信一郎, 岡根 功, 日本金属学会誌, 58-10 (1994) 1191.

12）福本昌宏, 加藤信一郎, 大渡智喜, 黄 覀輝, 日本金属学会誌, 59-11 (1995) 1178.

13）黄 亜輝, 大渡智喜, 福本昌宏, 日本金属学会誌, 60-12(1996) 1215.

14）福本昌去，林 宏道，横山 剛，溶射，32-3（1995） 149 .

15）福本昌宏, 横山 剛, 奥 一也, 田中康徳, 高温学会誌, 3(1997) 240.

16) E.W. Collings, A.J. Markworth, J.K. McCoy and J.H. Saunders, J. Mat. Sci, 25 (1990) 3677.

17) T. Bennett and D. Poulikakos, J. Mat. Sci., 29 (1994) 2025.

18）平田好則, 松本泰一, 丸尾 大, 小澤拓生, 黄地尚義, 高温学会 誌，23 (1997) 222.

19）西岡映二，福本昌去，溶接学会論文集 投稿中.

20）日本金属学会編，金属データブック（改訂 3 版），丸善 (1993) 16.

21) B. Kang, J. Waldvogel and D. Poulikakos, J. Mat. Sci., 30 (1995) 4912.

22) L. Bianchi, A.C. Lager, M. Vardelle, A. Vardelle and P. Fauchais, Thin Solid Films, 305 (1997) 35.

23) C. Moreau, P. Gougeon and M. Lamontagne, J. Thermal Spray Tech., 4 (1995) 25.

24) Robert C., Vardelle A., Wang G.X., Jiang X.Y. and Sampath S., Proc. 15th ITSC, 1 (1998) 720.

25) R.F. Allen, J. Colloid and Int. Sci., 62-3 (1975) 350.

26) S. Chandrasekhar, Hydrodynamics and hydromagnetics Stability, Oxford University Press,London (1961) 435.

27) L. Rayleigh, Proc. Lond. Math. Soc., 10 (1878) 4.

$$
\text { 謝辞 }
$$

本研究は, 文部省科学研究費補助金·基盤研究(C)(2)の援助によった。 記してここに謝意を表す。 